\title{
Geochemistry of PGE in mafic rocks of east Khasi Hills, Shillong Plateau, NE India
}

\author{
Sampa Hazra ${ }^{1}$, Jyotisankar Ray ${ }^{1, *}$, C Manikyamba ${ }^{2}$, Abhishek Saha ${ }^{1}$ and S S Sawant ${ }^{2}$ \\ ${ }^{1}$ Department of Geology, University of Calcutta, 35 Ballygunge Circular Road, Kolkata 700 019, India. \\ ${ }^{2}$ Geochemistry Division, National Geophysical Research Institute, Uppal Road, Hyderabad 500 007, India. \\ *Corresponding author. e-mail: jsray65@hotmail.com
}

The mafic rocks of east Khasi Hills of the Meghalaya Plateau, northeastern India, occur as an intrusive body which cut across the weakly metamorphosed Shillong Group of rocks. Other than Shillong Group of rocks, high grade Archaean gneissic rocks and younger porphyritic granites are also observed in the study area. The studied mafic rocks of east Khasi Hills cover an area of about $4 \mathrm{~km}^{2}$ and represent structurally controlled intrusion and varying grades of deformation. Structurally, these mafic rocks can be divided into massive type of mafic rocks, which are more or less deformation free and foliated type of mafic rocks that experienced deformation. Petrographically, this massive type can be classified as leuco-hornblende-gabbro whereas foliated type can be designated as amphibolite. On the basis of major oxide geochemistry, the investigated mafic rocks can be discriminated into high titanium (HT) $\left(\mathrm{TiO}_{2}>2 \mathrm{wt} \%\right)$ and low titanium (LT) types $\left(\mathrm{TiO}_{2}<2 \mathrm{wt} \%\right)$. Use of several geochemical variation diagrams, consideration of chondrite-normalized and mantle-normalized REE and PGE plots suggest role of magmatic differentiation (with almost no role of plagioclase fractionation) in a subduction controlled tectonic environment. The PGE trends of the studied rocks suggest relative enrichment of palladium group of PGE (PPGE) compared to iridium group PGE (IPGE). Critical consideration of Sm vs. La, $\mathrm{Cu}$ vs. $\mathrm{La}, \mathrm{Pd}$ vs. $\mathrm{La}$ and $\mathrm{Cu} / \mathrm{Pd}$ vs. $\mathrm{La} / \mathrm{Sm}$ plots strongly favours generation of the parent magma at a columnar melting regime with batch melting of cylindrical column of the parent mantle to the tune of $\sim 25 \%$. The characteristic PGE behaviours of the presently investigated mafic rocks of east Khasi Hills can be typically corroborated as 'orogenic' (discordant) type. These rocks have an enriched mantle affinity with a co-magmatic lineage and they have been generated by slab-dehydration, wedge-melting and assimilation fractional crystallization process at a continental margin arc setting.

\section{Introduction}

Platinum group of elements (namely $\mathrm{Pd}, \mathrm{Pt}, \mathrm{Rh}$, $\mathrm{Ru}$, Ir and Os) are associated with mafic or ultramafic intrusions, which are products of crystallization of a parental magma containing several ppb levels of Pd or Pt (Momme et al. 2006). The platinum group of elements (PGE) are commonly subdivided into the Pt group (viz., Pd, Pt, Rh) and Ir group (viz., Ru, Ir, Os). Ir group of PGE are normally compatible during moderate to high degree of batch melting of cylindrical column or during fractional crystallization. On the other hand, $\mathrm{Au}$, $\mathrm{Pd}, \mathrm{Pt}$ and $\mathrm{Rh}$ are normally incompatible and they would tend to be concentrated into the melt phase. However, Au, Pt group PGE, and Ir group PGE all have a tendency to be incorporated into the sulphide minerals (Vaillancourt et al. 2003). In other

Keywords. PGE geochemistry; mafic rocks of east Khasi Hills; northeastern India; mantle melting regime; orogenic discordant type. 
words, the extremely high distribution coefficient $\left(\mathrm{K}_{\mathrm{D}}\right)$ for PGE between sulphide and magma suggest that PGE rich magmas can only form, if all the sulphides are melted out of the mantle (Momme et al. 2006). It is generally considered that the average degree of mantle melting should exceed $20 \%$, assuming standard peridotite mantle contains $250 \pm 50$ ppm sulphur (McDonough and Sun 1995). The importance of PGE had been widely appreciated and those PGE were extensively studied to identify basic geochemical control for their formation and characterization in the earth's crust, which is in turn related to primary mantle derived magmatic process (Brügmann et al. 1993; Rekhamper et al. 1999; Momme et al. 2002, 2003; Crocket and Paul 2004; Balaram 2008; Qi and Zhou 2008; Song et al. 2009; Keays and Lightfoot 2010; Mondal 2011). Geochemistry of PGE has also been used for elucidation of PGE deposits in different geological and tectonic settings (Li et al. 2009; Naldrett 2010). During magmatic crystallization, the chalcophile elements can be broadly divided into compatible group (Ni, Co, Os, Ir, Ru) and incompatible group ( $\mathrm{Cu}, \mathrm{Ag}, \mathrm{Au}$ and $\mathrm{Pd})$. During magmatic crystallization, the $\mathrm{PG}$ elements are partitioned more favourably to the sulphides rather than to $\mathrm{Ni}$ and $\mathrm{Cu}$. Therefore, the magmas which have suffered removal of sulphides will be depleted in PGE (Barnes and Maier 1999). In general, the ultramafic igneous bodies (which have good prospect of PGE studies) could be broadly divided into two categories (Balaram et al. 2013) on the basis of their occurrence which are as follows:

- PGE as by-product in massive $\mathrm{Ni}-\mathrm{Cu}$ deposits (Hudson et al. 1978; Lesher and Barnes 2009) and

- dominant PGE deposits with $\mathrm{Ni}-\mathrm{Cu}$ as byproduct (Maier et al. 1996; Maier 2005; Naldrett et al. 2009).

In contrast to the global scenario, attempts for PGE investigations in Indian context are still very limited (Srivastava et al. 2010; Balaram et al. 2013). However, PGE have been reported from several plutonic to hypabyssal Indian magmatic intrusions of Archean-Paleoproterozoic age (Balaram 2008; Mukherjee 2010). Some of the path-breaking studies in Indian scenario include Sukinda and Baula-Nausahi of Orissa in Singhbhum craton (Auge et al. 2002; Mondal et al. 2007), Sittampundi complex of Tamil Nadu, Southern Granulite Belt (Satyanarayanan et al. 2008, 2010b) and Hanumalapura of Karnataka in Dharwar Craton (Devaraju et al. 2005; Alapieti et al. 2008) and in Ikauna-Madawara areas on Bundelkhand Craton, central India (Farooqui and Singh 2006; Singh et al. 2010a, b; Satyanarayanan et al. 2010a, 2011;
Balaram et al. 2013). Beside these above studies, PGE investigations have also been carried out (in small areas though) in other parts of India (Mukherjee 2010; Nathan 2010; Dora et al. 2011). PGE studies have immense importance in unravelling petrogenetic aspects and tectonic implications of the source rock. Hence, in this paper, an attempt has been made to highlight the significance of newly generated PGE data on mafic rocks of east Khasi Hills. A fresh batch of 11 samples of mafic rocks of east Khasi Hills have been analyzed for major, minor, trace (including REE) and PGE contents and the output data have been presented in this paper. Such PGE studies on investigated mafic rocks of east Khasi Hills of northeastern India have been taken up for the first time and they play important role in constraining petrogenetic aspects considered in conjunction with REE and other data. The major, minor, trace, and PGE contents have been presented in tables 1-3.

\section{Geological setting}

The different rock units exposed in Meghalaya plateau are: Archaean gneissic complex, Shillong Group of rocks (previously known as Shillong series), mafic rocks of east Khasi Hills (known as 'Khasi greenstone' in previous literature), porphyritic granite, Sylhet traps, and younger sediments. Geological succession of the Meghalaya plateau was presented by Mazumder (1986) based on the original work of West (1949). From the geological succession it is apparent that the mafic rocks of east Khasi Hills occur as intrusives into the Shillong group of rocks and might be invaded by the younger porphyritic granite. The generalized succession (after Mazumder 1986) is given below:

Mesozoic-Tertiary sedimentary rocks Unconformity-

Sylhet Traps of pre-Upper Cretaceous age

Fault contact-

Porphyritic granite

-Intrusive contact-

Mafic rocks of east Khasi Hills ('Khasi greenstone')

Shillong Group

Unconformity-

Non-porphyritic migmatitic granitoid

Diffused contact-

Archaean Basement Gneissic Complex 
Table 1. Major oxide data (wt\%) of Khasi mafic rocks.

\begin{tabular}{|c|c|c|c|c|c|c|c|c|c|c|c|}
\hline Sp. no. & SH-11B & SH-29 & SH-113 & SH-119 & SH-120 & SH-13B & SH-26 & SH-59 & SH-116 & SH-118 & SH-108C \\
\hline $\mathrm{SiO}_{2}$ & 49.55 & 49.15 & 49.57 & 50.67 & 49.28 & 52.03 & 48.19 & 56.34 & 49.23 & 48.27 & 49.02 \\
\hline $\mathrm{TiO}_{2}$ & 4.30 & 2.35 & 2.13 & 3.83 & 2.55 & 1.81 & 1.41 & 1.37 & 1.53 & 1.69 & 1.54 \\
\hline $\mathrm{Al}_{2} \mathrm{O}_{3}$ & 10.79 & 12.38 & 11.55 & 11.14 & 12.57 & 11.55 & 13.13 & 12.58 & 12.82 & 13.05 & 15.10 \\
\hline${ }^{*} \mathrm{Fe}_{2} \mathrm{O}_{3}$ & 3.56 & 3.11 & 2.79 & 3.37 & 3.48 & 4.12 & 3.21 & 3.37 & 2.65 & 3.07 & 2.81 \\
\hline$* \mathrm{FeO}$ & 9.98 & 8.70 & 7.80 & 9.43 & 9.75 & 11.53 & 8.99 & 9.43 & 7.42 & 8.59 & 7.88 \\
\hline $\mathrm{MnO}$ & 0.34 & 0.22 & 0.21 & 0.29 & 0.22 & 0.28 & 0.22 & 0.19 & 0.18 & 0.19 & 0.20 \\
\hline $\mathrm{MgO}$ & 6.35 & 8.28 & 10.12 & 6.28 & 6.58 & 3.32 & 9.61 & 2.02 & 10.60 & 10.60 & 9.05 \\
\hline $\mathrm{CaO}$ & 8.22 & 8.72 & 8.67 & 8.51 & 8.22 & 6.59 & 9.04 & 4.51 & 9.79 & 9.02 & 9.01 \\
\hline $\mathrm{Na}_{2} \mathrm{O}$ & 3.52 & 2.81 & 3.09 & 2.24 & 2.76 & 4.01 & 2.14 & 4.35 & 2.06 & 2.12 & 2.09 \\
\hline $\mathrm{K}_{2} \mathrm{O}$ & 1.20 & 1.59 & 1.01 & 1.55 & 1.23 & 2.01 & 1.32 & 2.96 & 0.88 & 0.75 & 1.14 \\
\hline $\mathrm{P}_{2} \mathrm{O}_{5}$ & 0.65 & 0.35 & 0.28 & 0.48 & 0.45 & 0.50 & 0.19 & 0.22 & 0.18 & 0.25 & 0.20 \\
\hline LOI & 0.52 & 0.98 & 1.60 & 1.22 & 1.50 & 0.70 & 1.20 & 1.33 & 1.34 & 1.09 & 0.75 \\
\hline Total & 98.98 & 98.64 & 98.81 & 99.00 & 98.60 & 98.45 & 98.65 & 98.66 & 98.69 & 98.69 & 98.79 \\
\hline $\mathrm{Na}_{2} \mathrm{O}+\mathrm{K}_{2} \mathrm{O}$ & 4.72 & 4.40 & 4.10 & 3.79 & 3.99 & 6.02 & 3.46 & 7.31 & 2.94 & 2.87 & 3.23 \\
\hline$* * \mathrm{Mg} \#$ & 39 & 49 & 56 & 40 & 40 & 22 & 52 & 18 & 59 & 55 & 53 \\
\hline \multicolumn{12}{|l|}{ CIPW norm } \\
\hline Quartz & 0.89 & - & - & 6.52 & 1.48 & 1.10 & - & 5.12 & - & - & - \\
\hline Orthoclase & 7.09 & 9.40 & 5.97 & 9.16 & 7.27 & 11.88 & 7.80 & 17.49 & 5.20 & 4.43 & 6.74 \\
\hline Albite & 29.79 & 23.78 & 26.15 & 18.95 & 23.35 & 33.93 & 18.11 & 36.81 & 17.43 & 17.94 & 17.68 \\
\hline Anorthite & 10.10 & 16.47 & 14.66 & 15.76 & 18.28 & 7.58 & 22.32 & 6.06 & 23.13 & 23.88 & 28.45 \\
\hline Diopside & 21.48 & 19.82 & 21.28 & 18.94 & 15.99 & 18.45 & 17.23 & 12.69 & 19.46 & 15.49 & 12.06 \\
\hline Hypersthene & 14.29 & 11.72 & 11.55 & 15.18 & 19.80 & 14.24 & 15.52 & 11.18 & 21.46 & 22.13 & 22.92 \\
\hline Olivine & - & 6.70 & 8.88 & - & - & - & 8.70 & - & 3.49 & 5.49 & 2.73 \\
\hline Magnetite & 5.16 & 4.51 & 4.05 & 4.89 & 5.05 & 5.97 & 4.65 & 4.89 & 3.84 & 4.45 & 4.07 \\
\hline Ilmenite & 8.17 & 4.46 & 4.05 & 7.27 & 4.84 & 3.44 & 2.68 & 2.60 & 2.91 & 3.21 & 2.92 \\
\hline Apatite & 1.51 & 0.81 & 0.65 & 1.11 & 1.04 & 1.16 & 0.44 & 0.51 & 0.42 & 0.58 & 0.46 \\
\hline D.I. & 37.77 & 33.18 & 32.12 & 34.63 & 32.10 & 46.91 & 25.91 & 59.42 & 22.63 & 22.37 & 24.42 \\
\hline
\end{tabular}

* $\mathrm{FeO}$ and $\mathrm{Fe}_{2} \mathrm{O}_{3}$ proportions discriminated using stipulated $\mathrm{FeO} / \mathrm{Fe}_{2} \mathrm{O}_{3}$ ratios (Cox et al. 1979).

$* * \mathrm{Mg} \#=[\mathrm{MgO} / \mathrm{MgO}+\mathrm{FeO})] \times 100$.

\section{Petrographic notes}

\subsection{Massive type}

It comprises coarse grained, inequigranular rocks, essentially composed of plagioclase, actinolite, relict pyroxene, biotite and opaque minerals (either magnetite or ilmenite, see Hazra et al. 2008). Carbonate minerals are seldom present. Plagioclase crystals are medium grained, lath shaped and highly saussuritized. Actinolite grains occur mostly as secondary after pyroxene (Ray et al. 2013). Some of the actinolite grains contain inclusions of lath shaped plagioclase and opaque minerals mostly magnetite. Sometimes quartz grains occur in association with recrystallised plagioclase as small, equidimensional irregular grains and also as inclusions within amphibole.

\subsection{Foliated type}

It includes medium grained variety consisting of plagioclase, actinolite with biotite, epidote, sphene, magnetite, ilmenite and apatite as accessory minerals. In this type, plagioclase occurs as medium to fine grained lath shaped subidioblastic grains. Some of the grains are coarse in nature occurring as large porphyroblast. Most of the plagioclase grains are saussuritized and show cloudy appearance due to the presence of secondary minerals like muscovite, sericite and epidote. Actinolite is secondary in nature and formed from primary pyroxene. Sphene occurs as tiny idioblastic rhombic crystals whereas apatite occurs as elliptical grains. Well developed opaque grains are formed at the expense of relict pyroxene and actinolite. Texturally, these rocks show an overall nematoblastic texture defined by the prismatic amphibole grains. These mafic intrusives have undergone low grade metamorphic reconstitution (Ray et al. 2013).

It is important to note that both the massive type and foliated type have broadly identical mineral assemblages. But from field and petrographic studies it appears that (i) the massive type retains igneous textures and (ii) the foliated type is reconstituted due to later deformation. In view of retention of igneous signature, it would therefore be worthwhile to classify the massive 
Table 2. Trace element data $(\mu \mathrm{g} / \mathrm{g})^{\$}$ of Khasi mafic rocks.

\begin{tabular}{|c|c|c|c|c|c|c|c|c|c|c|c|}
\hline Sp. no. & SH-11B & SH-29 & SH-113 & SH-119 & SH-120 & SH-13B & SH-26 & SH-59 & SH-116 & SH-118 & SH-108C \\
\hline $\mathrm{Cr}$ & 0.73 & 4.07 & 4.10 & 1.21 & 2.06 & 0.73 & 2.98 & 0.60 & 3.15 & 3.25 & 3.11 \\
\hline $\mathrm{Co}$ & 35.97 & 74.81 & 78.99 & 57.82 & 37.15 & 39.44 & 62.23 & 33.11 & 55.41 & 53.04 & 57.12 \\
\hline $\mathrm{Ni}$ & 0.45 & 3.69 & 5.34 & 0.74 & 1.65 & 0.35 & 18.37 & 0.36 & 13.77 & 11.76 & 13.26 \\
\hline $\mathrm{Rb}$ & 14.37 & 28.13 & 17.16 & 24.05 & 20.14 & 32.50 & 32.72 & 30.23 & 13.02 & 11.08 & 10.21 \\
\hline $\mathrm{Sr}$ & 136.50 & 180.61 & 141.21 & 113.20 & 169.10 & 120.71 & 163.34 & 73.01 & 148.86 & 162.58 & 150.23 \\
\hline Cs & 9.28 & 42.80 & 10.66 & 57.66 & 16.48 & 26.09 & 85.30 & 11.68 & 18.17 & 34.56 & 18.34 \\
\hline $\mathrm{Ba}$ & 343.20 & 698.75 & 219.18 & 731.33 & 509.92 & 1170.11 & 290.40 & 890.04 & 307.70 & 186.10 & 306.70 \\
\hline $\mathrm{Sc}$ & 68.16 & 59.24 & 58.65 & 70.72 & 54.53 & 41.85 & 42.03 & 25.76 & 43.77 & 51.05 & 42.77 \\
\hline $\mathrm{V}$ & 346.49 & 630.40 & 544.45 & 680.43 & 505.09 & 13.35 & 347.22 & 4.76 & 382.76 & 445.35 & 381.76 \\
\hline $\mathrm{Ta}$ & 0.17 & 0.08 & 0.07 & 0.12 & 0.10 & 0.19 & 0.04 & 0.59 & 0.04 & 0.05 & 1.04 \\
\hline $\mathrm{Nb}$ & 0.60 & 0.26 & 0.21 & 0.41 & 0.35 & 0.66 & 0.13 & 2.30 & 0.14 & 0.16 & 0.24 \\
\hline $\mathrm{Zr}$ & 57.33 & 15.34 & 23.71 & 41.31 & 27.93 & 93.42 & 5.95 & 192.75 & 6.72 & 10.06 & 7.72 \\
\hline $\mathrm{Hf}$ & 1.72 & 0.54 & 0.73 & 1.26 & 0.87 & 2.80 & 0.22 & 5.57 & 0.24 & 0.33 & 0.28 \\
\hline Th & 1.42 & 0.57 & 0.46 & 1.02 & 0.92 & 2.39 & 0.23 & 4.50 & 0.23 & 0.26 & 0.24 \\
\hline $\mathrm{U}$ & 0.43 & 0.17 & 0.16 & 0.33 & 0.31 & 0.71 & 0.07 & 1.05 & 0.08 & 0.09 & 0.08 \\
\hline $\mathrm{Y}$ & 58.30 & 34.13 & 28.98 & 48.22 & 43.63 & 78.24 & 16.65 & 110.22 & 17.18 & 20.39 & 18.17 \\
\hline $\mathrm{Cu}$ & 34.09 & 205.09 & 234.84 & 482.31 & 226.20 & 24.10 & 21.06 & 98.35 & 107.78 & 163.99 & 108.78 \\
\hline $\mathrm{Zn}$ & 87.55 & 70.30 & 89.38 & 99.83 & 68.93 & 97.27 & 76.87 & 76.52 & 54.22 & 59.38 & 52.22 \\
\hline $\mathrm{Pb}$ & 20.24 & 13.91 & 14.93 & 16.72 & 24.01 & 18.01 & 22.27 & 30.06 & 13.60 & 20.05 & 14.60 \\
\hline $\mathrm{Ni} / \mathrm{Co}$ & 0.01 & 0.05 & 0.07 & 0.01 & 0.04 & 0.01 & 0.30 & 0.01 & 0.25 & 0.22 & 0.23 \\
\hline $\mathrm{Ni} / \mathrm{Cu}$ & 0.01 & 0.02 & 0.02 & 0.00 & 0.01 & 0.01 & 0.87 & 0.00 & 0.13 & 0.07 & 0.12 \\
\hline $\mathrm{Th} / \mathrm{Ta}$ & 8.63 & 6.88 & 6.72 & 8.68 & 9.34 & 12.49 & 5.79 & 7.67 & 6.03 & 5.38 & 0.23 \\
\hline \multicolumn{12}{|c|}{ Rare earth element data $(\mu \mathrm{g} / \mathrm{g})^{\$}$} \\
\hline La & 4.71 & 2.10 & 1.75 & 3.00 & 3.07 & 5.43 & 1.01 & 12.80 & 1.05 & 1.23 & 1.10 \\
\hline $\mathrm{Ce}$ & 11.96 & 5.70 & 4.79 & 8.06 & 8.13 & 14.98 & 2.80 & 31.88 & 2.84 & 3.33 & 2.93 \\
\hline $\operatorname{Pr}$ & 1.68 & 0.80 & 0.67 & 1.13 & 1.13 & 1.98 & 0.39 & 4.13 & 0.39 & 0.47 & 0.34 \\
\hline $\mathrm{Nd}$ & 11.35 & 5.41 & 4.59 & 7.64 & 7.49 & 12.76 & 2.70 & 25.77 & 2.71 & 3.31 & 2.80 \\
\hline $\mathrm{Sm}$ & 3.87 & 1.91 & 1.62 & 2.71 & 2.57 & 4.34 & 0.96 & 8.16 & 0.97 & 1.18 & 0.97 \\
\hline $\mathrm{Eu}$ & 1.19 & 0.79 & 0.64 & 0.98 & 0.95 & 1.43 & 0.39 & 2.54 & 0.42 & 0.52 & 0.43 \\
\hline $\mathrm{Gd}$ & 5.82 & 3.05 & 2.50 & 4.21 & 4.00 & 6.59 & 1.50 & 11.90 & 1.55 & 1.84 & 1.54 \\
\hline $\mathrm{Tb}$ & 1.21 & 0.65 & 0.53 & 0.92 & 0.85 & 1.46 & 0.32 & 2.41 & 0.33 & 0.40 & 0.34 \\
\hline Dy & 7.60 & 4.30 & 3.59 & 5.88 & 5.52 & 9.78 & 2.07 & 15.08 & 2.16 & 2.59 & 2.16 \\
\hline Ho & 1.82 & 1.07 & 0.91 & 1.51 & 1.41 & 2.50 & 0.54 & 3.61 & 0.55 & 0.67 & 0.53 \\
\hline Er & 6.31 & 3.79 & 3.21 & 5.39 & 4.89 & 9.09 & 1.90 & 12.22 & 1.88 & 2.28 & 1.89 \\
\hline $\mathrm{Tm}$ & 1.20 & 0.70 & 0.61 & 1.03 & 0.92 & 1.76 & 0.35 & 2.21 & 0.37 & 0.42 & 0.38 \\
\hline $\mathrm{Yb}$ & 7.09 & 4.20 & 3.64 & 6.15 & 5.43 & 10.97 & 2.10 & 12.69 & 2.14 & 2.51 & 2.15 \\
\hline $\mathrm{Lu}$ & 1.17 & 0.66 & 0.60 & 1.01 & 0.86 & 1.78 & 0.35 & 1.96 & 0.34 & 0.41 & 0.36 \\
\hline$\sum \mathrm{REE}$ & 66.97 & 35.12 & 29.63 & 49.61 & 47.21 & 84.83 & 17.37 & 147.35 & 17.68 & 21.15 & 17.91 \\
\hline$(\mathrm{La} / \mathrm{Yb})$ & 0.66 & 0.50 & 0.48 & 0.49 & 0.57 & 0.49 & 0.48 & 1.01 & 0.49 & 0.49 & 0.51 \\
\hline$(\mathrm{La} / \mathrm{Sm})_{\mathrm{N}}$ & 0.79 & 0.71 & 0.70 & 0.71 & 0.77 & 0.81 & 0.68 & 1.01 & 0.70 & 0.67 & 0.73 \\
\hline (La/Sm) & 1.22 & 1.10 & 1.08 & 1.11 & 1.19 & 1.25 & 1.05 & 1.57 & 1.08 & 1.04 & 1.14 \\
\hline
\end{tabular}

$\$(\mu \mathrm{g} / \mathrm{g})=\mathrm{ppm}$.

type of mafic rocks on the basis of IUGS recommended plagioclase-pyroxene-hornblende (actinolite) triangular diagram (Streckeisen 1976). The foliated type (as this is reconstituted), on the other hand, would be better classified in terms of triangular diagram (amphibole-plagioclase- quartz + biotite) recommended for basic metamorphic rocks (Suk 1983).

For massive type, the plots fall mainly within hornblende-gabbro field with a rare spill to pyroxenehornblende-gabbro/norite field (Streckeisen 1976).
The modal data of the foliated type are clustered in the field of amphibolites (Suk 1983).

\section{Analytical method and sample location/characterization}

Major and minor oxides $\left(\mathrm{SiO}_{2}, \mathrm{TiO}_{2}, \mathrm{Al}_{2} \mathrm{O}_{3}\right.$, $\mathrm{Fe}_{2} \mathrm{O}_{3}, \mathrm{MnO}, \mathrm{MgO}, \mathrm{CaO}, \mathrm{Na}_{2} \mathrm{O}, \mathrm{K}_{2} \mathrm{O}$ and $\mathrm{P}_{2} \mathrm{O}_{5}$ ) were determined in all the samples by XRF (Philips MagiXPRO-PW2440) at the CSIR-National 


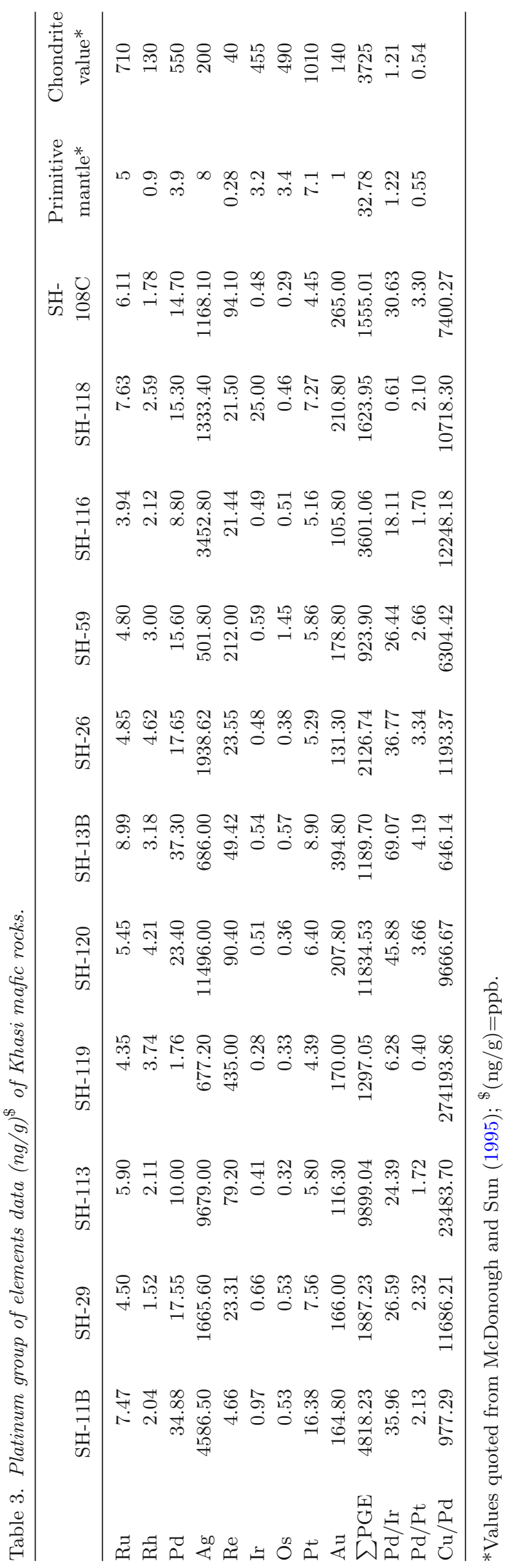

Geophysical Research Institute, Hyderabad, India. International geochemical certified reference materials (CRM) from the US Geological Survey, the Canadian Geological Survey, the International Working Group, France and NGRI, India, were used to prepare calibration curves for major oxides. Some minor and trace elements including rare earth elements (REE) and PGE were determined by ICP-MS (PerkinElmer SCIEX ELANDRC-II) at NGRI, Hyderabad (Balaram and Rao 2003). The analysis of PGE and $\mathrm{Au}$ was carried out by following NiS-fire assay method with Te coprecipitation and ICP-MS analysis described by Balaram et al. (2006). Single isotopes were used for all elements; they were selected based on their abundance levels and the freedom from interferences from other elements usually present in rock samples. The detection limits of most of the elements including PGE were about $0.01 \mathrm{ng} / \mathrm{ml}$, and the precision is better than $6 \% \mathrm{RSD}$ for trace and REE, and is $<10 \%$ RSD for PGE data.

Locations of analyzed samples are given in figure 1 and a brief petrographic note has been provided in table $4 . \mathrm{MgO}$ content of the samples varies from 10.60 to 2.02 and $\mathrm{SiO}_{2}$ content ranges from 56.34 to $48.19 \mathrm{wt} \%$. The wide variations of $\mathrm{SiO}_{2}$ and $\mathrm{MgO}$ have been reflected in terms of both 'olivine' and 'quartz' normative characters of the rocks (tables 1 and 4). Another interesting point is the range of $\mathrm{TiO}_{2}$ in the investigated rocks $\left(\mathrm{TiO}_{2}\right.$ ranging from 4.30 to $\left.1.37 \mathrm{wt} \%\right)$. Based on $\mathrm{TiO}_{2}$ (figure 2) content, the mafic rocks have been divided into two geochemical types, viz., low titanium (LT) type having $\mathrm{TiO}_{2}<2.00 \mathrm{wt} \%$ and high titanium (HT) type having $\mathrm{TiO}_{2}>2.00 \mathrm{wt} \%$. The investigated samples show both LT and HT affinity (table 4). Table 4, however, reveals that the geochemical types (HT or LT) are irrespective of their field names, namely foliated and massive type of mafic rocks. In other words, massive dyke might have both HT and LT geochemical affinities (Farm and Leshar 1997; Korenaga and Kelemen 2000; Momme et al. 2006). The same thing is true for foliated type as well (table 4).

\section{Results}

\subsection{Major, minor and trace elemenlts}

The major and minor oxides and trace element compositions (including REE and PGE contents) of the mafic rocks of east Khasi Hills are presented in tables 1-3. The accuracy of PGE data has been tested by analyzing international standards (CRM WMG-1 and CRM WRP-1) using same analytical set-up (table 5). The precision was assessed by analyzing three separate analyses of the CRM 


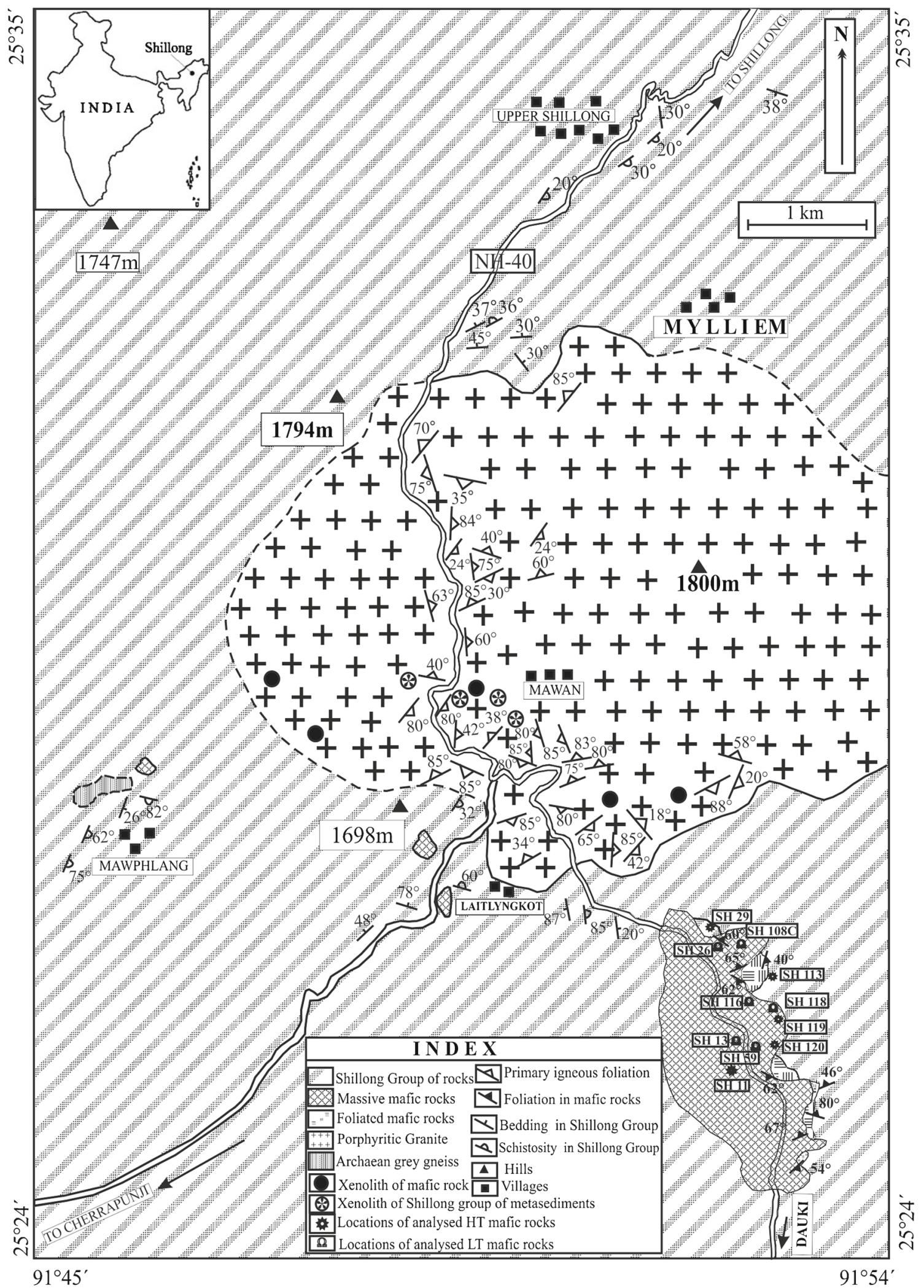

Figure 1. Map showing locations of the analyzed PGE samples for mafic rocks of east Khasi Hills. The geological map is from Ray et al. (2013). Inset shows location of the study area in a sketch map. 
Geochemistry of PGE in mafic rocks of east Khasi Hills

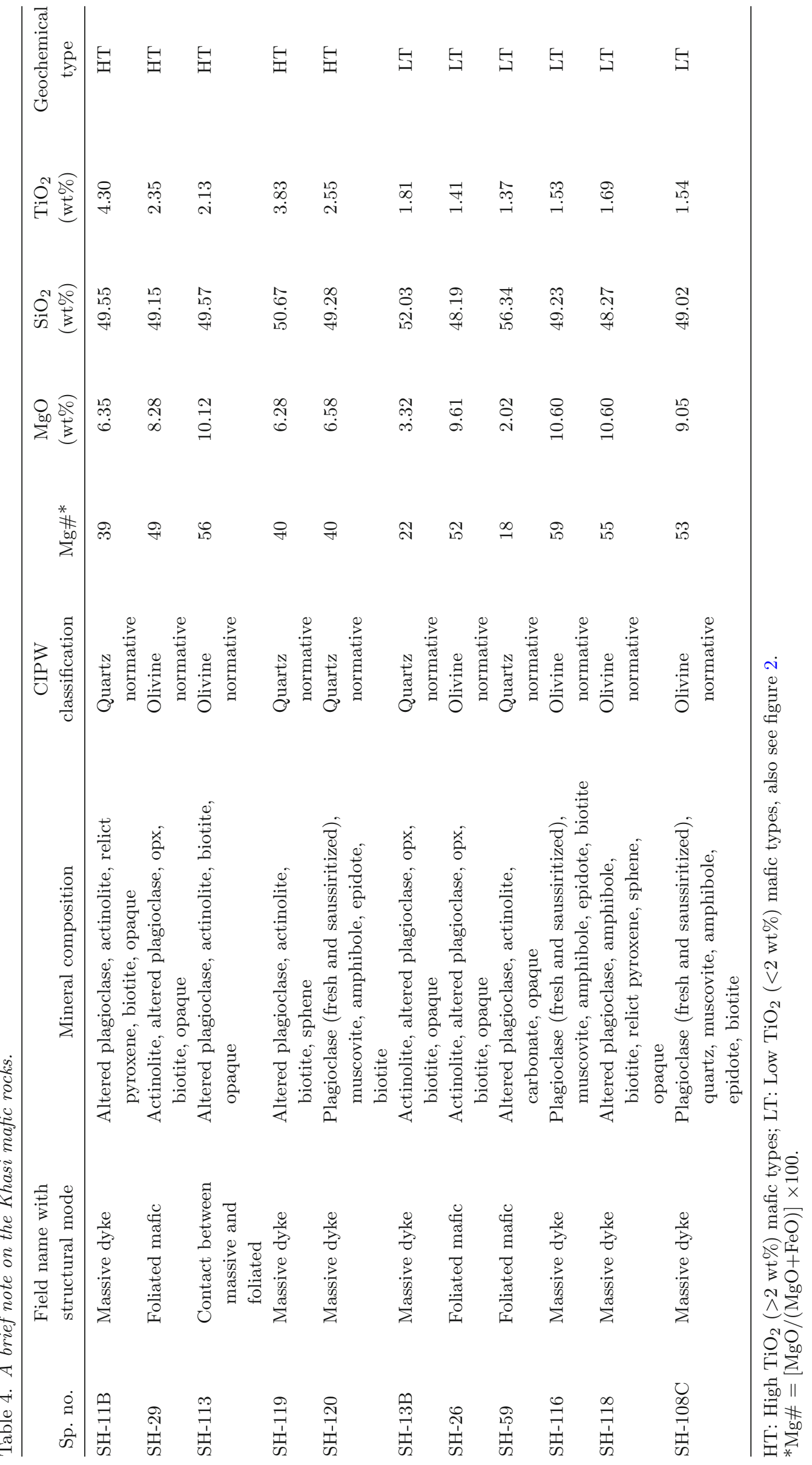


WMG-1; the values were found to be $<10 \%$ RSD. The investigated mafic rocks of east Khasi Hills are characterized by relatively low $\mathrm{MgO}$ (2.02$10.60 \mathrm{wt} \%)$, low $\mathrm{Fe}_{2} \mathrm{O}_{3}(2.65-4.12 \mathrm{wt} \%)$ and moderate $\mathrm{Al}_{2} \mathrm{O}_{3}(\sim 10.79-15.10 \mathrm{wt} \%)$, low to intermediate $\mathrm{SiO}_{2}(48.19-56.34 \mathrm{wt} \%)$ and variable $\mathrm{TiO}_{2}$ (1.37-4.30 wt\%). $\mathrm{Na}_{2} \mathrm{O}$ and $\mathrm{K}_{2} \mathrm{O}$ contents of the analyzed rocks show a spectrum of 2.06-4.35 wt\% and $0.75-2.96 \mathrm{wt} \%$. The mafic rocks have a relatively lower range of $\mathrm{Ni}$ from 0.35 to $18.37 \mathrm{ppm}$, while $\mathrm{Cu}$ content ranges from 21.06 to $482.31 \mathrm{ppm}$. ¿PGE of these mafic rocks, in general, have a range from 923.90 to $4818.23 \mathrm{ppb}$ (with the exception of two samples having higher $\sum \mathrm{PGE}$, to the tune of $\sim 10,000 \mathrm{ppb}$ ).

In order to understand the geochemical variation, several oxides and trace elements were plotted against respective $\mathrm{MgO}$ wt\% (figure $3 \mathrm{a}-\mathrm{d}$ ). $\mathrm{TiO}_{2}$ shows, in general, a negative relation with $\mathrm{MgO}$ (figure 3a). Moreover, as discussed earlier,

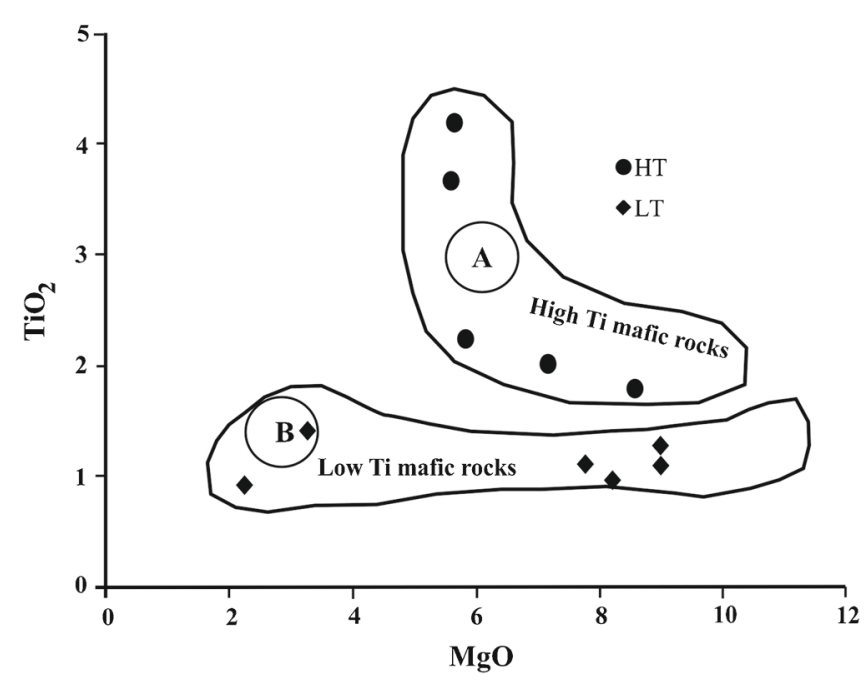

Figure 2. $\mathrm{TiO}_{2}$ vs. $\mathrm{MgO}$ diagram showing the distribution of analyzed plots into high Ti field (marked A) and low Ti field (marked B). Major oxides are in wt\%. this diagram forms an important basis for classifying the mafic rocks into high $\mathrm{TiO}_{2}(>2$ wt\%) and low $\mathrm{TiO}_{2}(<2$ wt\%) mafic types (table 4$)$ (figure 2). $\mathrm{SiO}_{2}$ (wt\%) shows a declining trend with rising $\mathrm{MgO}$ (wt\%) (figure 3b) while $\mathrm{CaO}$ (wt\%) and $\mathrm{Ni}$ (ppm) show a positive trend with $\mathrm{MgO}$ (figure $3 \mathrm{c}$ and d). Figure 3(e) shows $\sum \mathrm{PGE}$ vs. $\mathrm{Fe}_{2} \mathrm{O}_{3}$ plot where a broad positive trend is indicated which suggests primary magmatic character. Plots of $\mathrm{Cu}$ vs. $\mathrm{Ni}$ and $\mathrm{Pd}$ vs. Ni show distinct negative trends (figure $3 \mathrm{f}$ and $\mathrm{g}$ ) indicating role of magmatic differentiation.

The chondrite-normalized REE patterns of the mafic rocks have been shown in figure 4(a) with a generalized characteristic flat pattern for both LREE and HREE. Samples have a negative Sm anomaly; but none of the samples have positive $\mathrm{Eu}$ anomaly which suggests that there was no role of plagioclase fractionation. The negative $\mathrm{Sm}$ anomaly can be attributed to retention of garnet in the restite during mantle melting as it had earlier been discussed by Ray et al. (2013). They have categorically shown that during the production of the mafic magma, garnet was held in the source region during low degree of mantle melting. As the parent melt was generated in a 'garnet removed' scenario, the investigated Khasi mafic rocks show positive Sm anomaly. The flat HREE patterns indicate that garnet peridotite mantle was not the sole source of melting to generate the parent magma and possibly this also suggests melting above the garnet stability field. Primordial mantle normalized multi-element diagram (figure 4b) shows distinct peaks at Rb, Th, La and highly marked trough at Nb. The negative $\mathrm{Nb}$ anomaly suggests subduction zone magmatic regime (Sheraton et al. 1990; Zhao et al. 1995). In other parts of the world (as for example in Fosdik mountain, Antarctica), melting of the mantle at the continental margin arc-setting has given rise to abundant mafic intrusives (Satio et al. 2013). Interestingly, those mafic rocks bear very sharp negative $\mathrm{Nb}$ anomaly similar to our present study.

Table 5. Analytical data of geochemical standards WPR-1 and WMG-1. WPR-1 was used as calibration standard and WMG-1 was analyzed as an unknown to check accuracy (Balaram et al. 2013).

\begin{tabular}{|c|c|c|c|c|c|c|}
\hline \multirow[b]{2}{*}{ Element } & \multirow[b]{2}{*}{ Mass no. } & \multirow[b]{2}{*}{ Unit } & \multicolumn{2}{|c|}{ WPR-1 } & \multicolumn{2}{|c|}{ WMG-1 } \\
\hline & & & Certified value & $\begin{array}{c}\text { ICP-MS } \\
\text { obtained value }\end{array}$ & Certified value & $\begin{array}{c}\text { ICP-MS } \\
\text { obtained value }\end{array}$ \\
\hline $\mathrm{Ru}$ & 101 & $\mathrm{ng} / \mathrm{g}$ & 21.6 & $22.343 \pm 2$ & 27.6 & $35 \pm 2$ \\
\hline $\mathrm{Rh}$ & 103 & $\mathrm{ng} / \mathrm{g}$ & 13.4 & $13.067 \pm 1$ & 25.6 & $26 \pm 1.5$ \\
\hline $\mathrm{Pd}$ & 105 & $\mathrm{ng} / \mathrm{g}$ & 235.0 & $233.934 \pm 10$ & 307.8 & $382 \pm 18$ \\
\hline Os & 192 & $\mathrm{ng} / \mathrm{g}$ & 13.3 & $13.097 \pm 1.2$ & 14.6 & NA \\
\hline Ir & 193 & $\mathrm{ng} / \mathrm{g}$ & 13.5 & $13.671 \pm 1.5$ & 44.5 & $46 \pm 2$ \\
\hline $\mathrm{Pt}$ & 195 & $\mathrm{ng} / \mathrm{g}$ & 285.0 & $284.216 \pm 15$ & 892.0 & $861 \pm 41$ \\
\hline $\mathrm{Au}$ & 197 & $\mathrm{ng} / \mathrm{g}$ & 42.2 & $41.683 \pm 3$ & 82.4 & $102 \pm 5$ \\
\hline
\end{tabular}

Note. $(\mathrm{ng} / \mathrm{g})=\mathrm{ppb}$. 

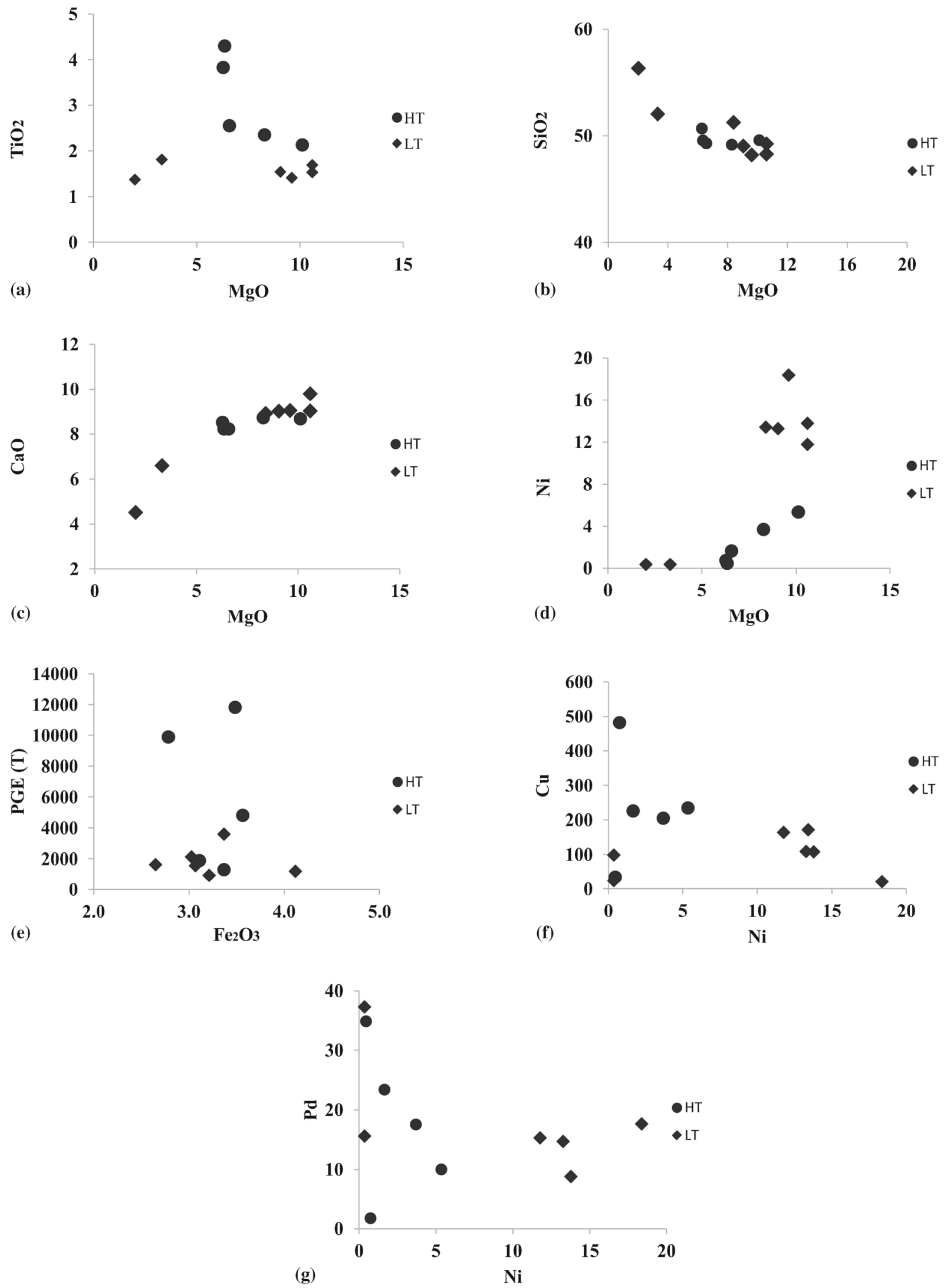

Figure 3. Chemical variation diagrams: (a-c) Plots of major oxides against $\mathrm{MgO}$; (d) plot of trace element (Ni) against $\mathrm{MgO}$; (e) plot of total PGE $[\mathrm{PGE}(\mathrm{T})]$ against $\mathrm{Fe}_{2} \mathrm{O}_{3}$; (f) and (g) represent plots of $\mathrm{Cu}$ vs. Ni and Pd vs. Ni, respectively. Major oxides are in wt\%. Cu and Ni values are in $\mu \mathrm{g} / \mathrm{g}(\mathrm{ppm})$. PGE(T) and Pd values in $\mathrm{ng} / \mathrm{g}(\mathrm{ppb})$. 

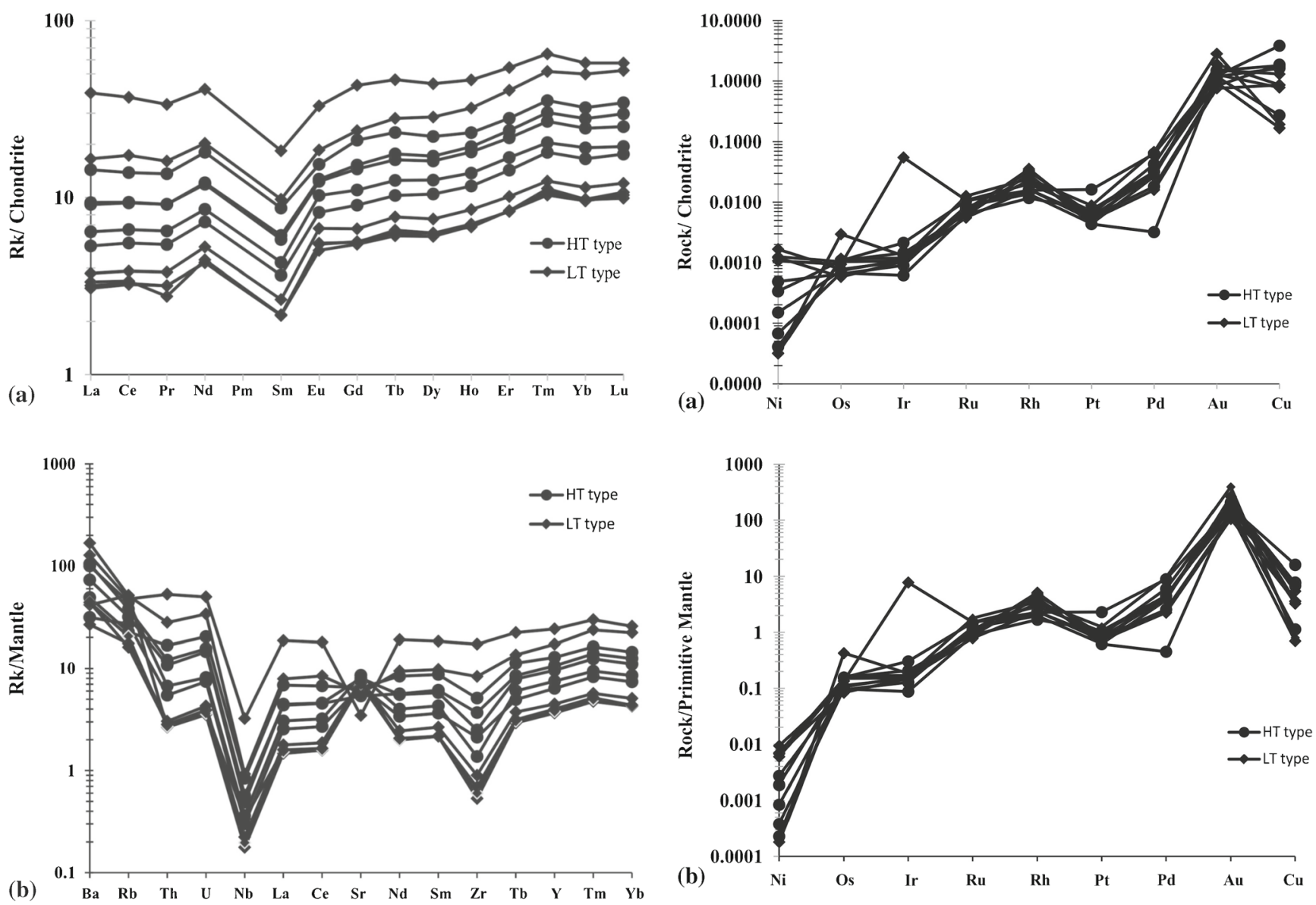

Figure 4. (a) Chondrite-normalized REE patterns for the mafic rocks of east Khasi Hills (normalizing values of chondrite after Nakamura 1974). (b) Primitive mantlenormalized multi-element diagram for the Khasi mafics (primitive mantle data after Sun and Mc Donough 1989).

\subsection{PGE distribution patterns in mafic rocks of east Khasi Hills}

The mafic rocks of east Khasi Hills show $\sum$ PGE concentrations from 923.90 to 4813.23 ppb (table 3) (with the exception of two samples having higher $\sum$ PGE to the tune of $\sim 10,000 \mathrm{ppb}$ ). Their Ir (0.28-0.97 ppb with a single exception where Ir $=25.00 \mathrm{ppb}), \mathrm{Ru}(3.94-8.99 \mathrm{ppb}), \mathrm{Rh}(1.52-$ $4.62 \mathrm{ppb}), \mathrm{Pt}$ (4.39-16.38 ppb), Pd (1.76-37.30 ppb), and $\mathrm{Au}$ (105.8-394.8 ppb) display relatively wide variations. The $\mathrm{Ni} / \mathrm{Cu}$ ratios of the mafic rocks (table 2) are found to be very low (0.002-0.87), which suggest that the mafic rocks do not have any affinity towards well-defined geological fields like 'Chromitites', 'Flood basalts', 'Layered intrusions', 'Cu rich sulphides', 'Ophiolite komatiites', etc. (Barnes et al. 1988).

Chondrite-normalized PGE plots (figure 5a) for the mafic rocks show a smooth pattern (Naldrett et al. 1979), similar to that found for rock-chondrite pattern (figure 4a). These PGE patterns usually provide useful clues about

Figure 5. (a) Chondrite-normalized PGE trends of mafic rocks of east Khasi Hills (normalizing values of chondrite after Mc Donough and Sun 1995). (b) Primitive mantlenormalized multi-element PGE trends for the mafic rocks of east Khasi Hills (normalizing values of mantle after Mc Donough and Sun 1995).

the fertile mantle, tectono-magmatic environments, fractionation-contamination history and fluid sulphide-silicate melt interactions during magmatic evolution (Barnes et al. 1985; Zhou et al. 2004a, b; Mondal et al. 2007; Alapieti et al. 2008). The PGE trends (figure 5a) of these mafic rocks suggest relative enrichment of Palladium group PGE (PPGE) (Rh, Pt, Pd) compared to Iridium group PGE (IPGE) (Ir and $\mathrm{Ru}$ ). The rock/ primitive mantle PGE trends (figure 5b) also show an enrichment of PPGE in comparison to that of IPGE.

\section{Discussion}

Siderophile (iron loving) elements are valuable geochemical tools because they have the potential to trace the mantle petrogenetic processes such as degree of batch melting of cylindrical column and an ambient melting regime (Momme et al. 2006; Woodland et al. 2002). Momme et al. (2002) showed that $\mathrm{Pd}, \mathrm{Cu}$, and La contents of both 
high titanium (HT) and low titanium (LT) mafic types of flood basalt provinces of eastern Greenland increase with differentiation and they were of the opinion that even though most differentiated magmas of the HT type represent $\sim 60 \%$ fractional crystallization, these magmas did not reach S-saturation. In order to test the variabilities of concentration of $\mathrm{Cu}, \mathrm{Pd}$, and $\mathrm{La}$ of the mafic rocks of east Khasi Hills, their respective concentrations were plotted with respect to $\mathrm{Mg} \#$ values (figure 6); $\mathrm{Cu}, \mathrm{Pd}$, and La show a general trend of scatter with very feeble tendency of increment with advent of differentiation (that is with fall of $\mathrm{Mg} \#$ ), a trend that was advocated by Momme et al. (2002), for mafic rocks of east Greenland. In a general mantle melting model, it is assumed that the mantle contains $250 \mathrm{ppm} \mathrm{S}$, the primary magma S-solubility is $1000 \mathrm{ppm} \mathrm{S}$ (Mathez 1976) and that the mantle melts $1 \%$ per $\mathrm{kb}$ decompression (Langmuir et al. 1992).

Modelling of PGE in magmas during mantle batch melting of cylindrical column has traditionally been based on batch melting of a columnar (cylindrical) melting regime (Keyas 1995; Barnes and Maier 1999). This model assumes that the mantle source melts uniformly in the entire melting regime and, as a consequence, these magmas extract all the sulphide hosted PGE from the mantle source once sulphide is exhausted. Therefore, it produces magmas with relatively high PGE concentration in high $\mathrm{F}$ (degree of melting) melts. In the columnar model, the mantle sulphide component is used up at $\mathrm{F} \sim 25 \%$ and $\mathrm{Cu}-\mathrm{Pd}-\mathrm{Pt}$ reached their maximum concentration at this stage. Batch melting of cylindrical column beyond $\sim 25 \%$ only dilutes the concentration of these chalcophile elements. Ir concentration on the other hand, is also hosted by non-sulphide mantle phases and the compatible behaviour leads to steady incremental concentration during progressive batch melting of cylindrical column even beyond $25 \%$. The $\mathrm{Cu} / \mathrm{Pd}$ ratio of the melts formed by $<25 \%$ batch melting of cylindrical column is $>100,000$ because $\mathrm{Pd}$ is much more efficiently retained in the residual mantle phase. When $\mathrm{F}$ exceeds $25 \%, \mathrm{Cu} / \mathrm{Pd}$ drops to the mantle value (around 6000).

The triangular melting regime (TMR) model is thought to be an appropriate analogue to melting beneath spreading ridges (Langmuir et al. 1992; Momme et al. 2003) and it assumes near fractional melting in 1\% melting step (Rekhamper et al. 1999; Momme et al. 2003). The TMR assumes perfect corner flow (Langmuir et al. 1992) (where initial melting takes place when the mantle crosses the solidus and as long as the mantle upwells vertically). The degree of batch melting of cylindrical column increases with vertical displacement (following the general principles of Langmuir et al.
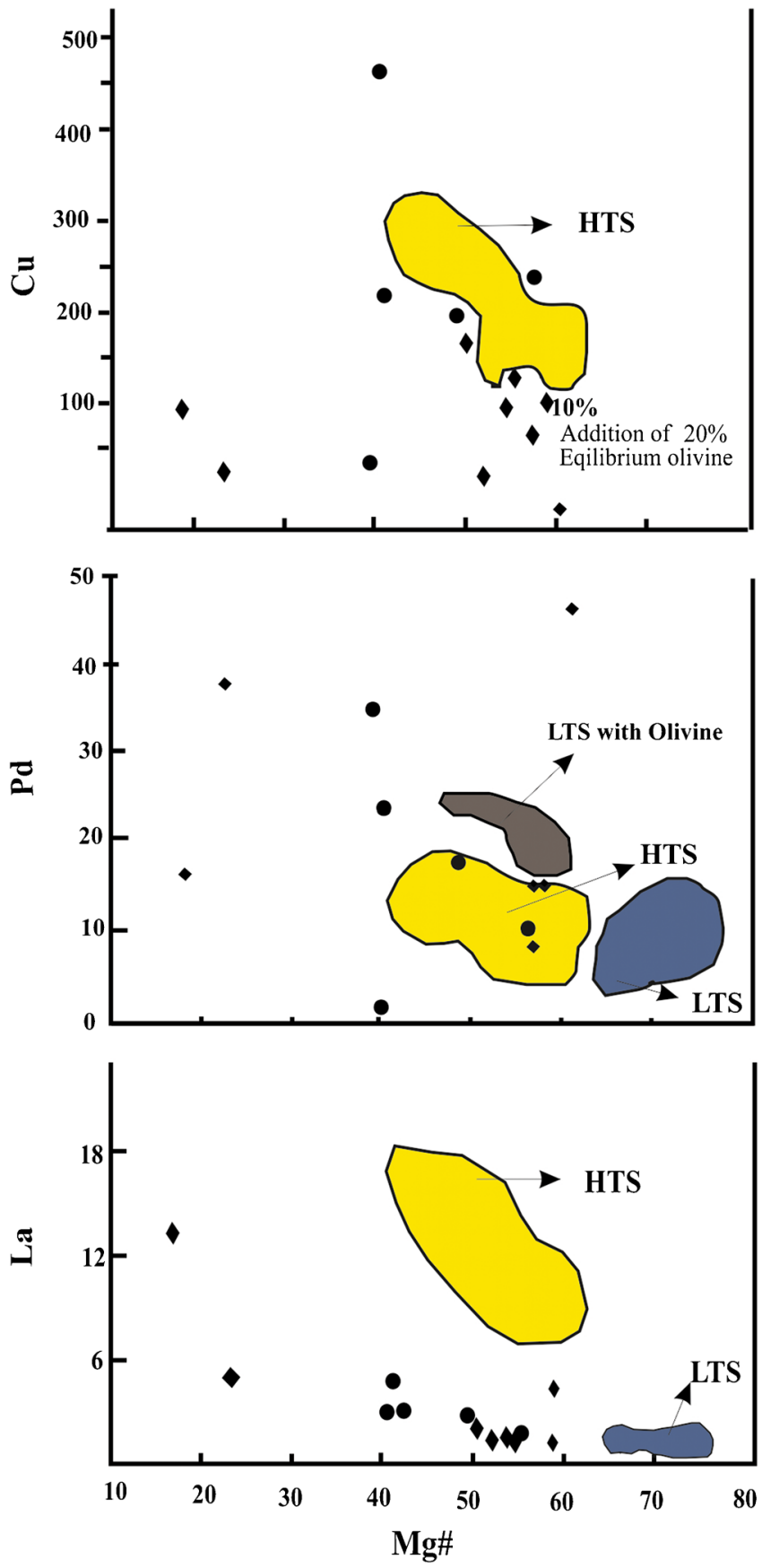

Figure 6. Plots of $\mathrm{Cu}, \mathrm{Pd}$ and La against $\mathrm{Mg \#}$. Fields of HTS (high Ti-suite) and LTS (low Ti-suite) are taken from Momme et al. (2006). Both the HTS and LTS samples show increasing concentrations of $\mathrm{Cu}, \mathrm{Pd}$ and La with decreasing $\mathrm{Mg} \#$ (that is with advent of differentiation). Solid circle represents high $\mathrm{Ti}$ type and solid diamond represents low Ti type. $\mathrm{Cu}$ and $\mathrm{La}$ values are in $\mu \mathrm{g} / \mathrm{g}(\mathrm{ppm})$. Pd values in ng/g (ppb).

1992); low degree melts form in the distal and lowest parts of the TMR. Such low F magmas are S-saturated at source with low PGE concentration and high $\mathrm{Cu} / \mathrm{Pd}$ greater than 100,000 . Thus it is evident that the melting process is broadly controlled by CMR (cylindrical) with degree of batch melting of cylindrical column by and large greater 

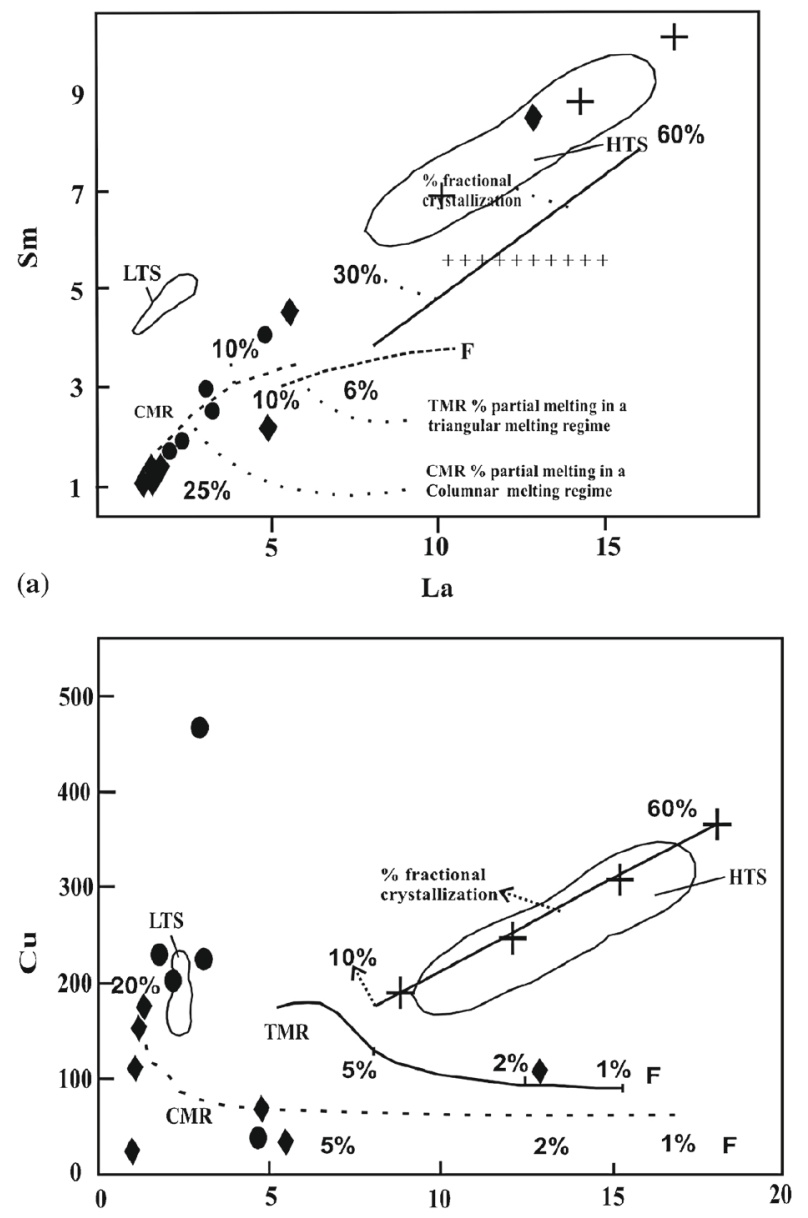

(b)

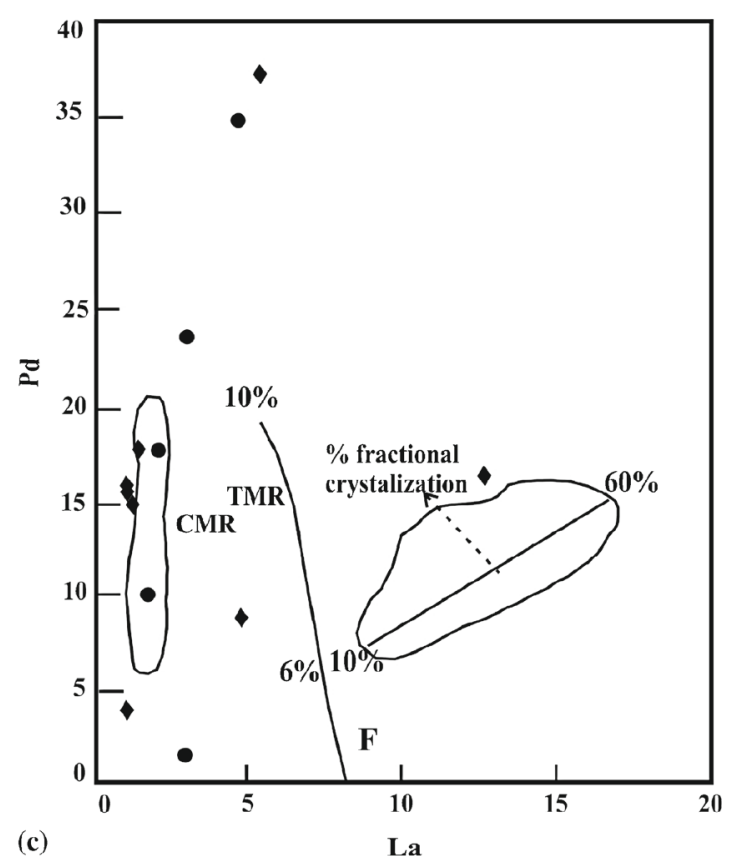

(c)

La

Figure 7. (a-c) Scatter diagram of $\mathrm{Sm}$ vs. La, Cu vs. La and $\mathrm{Pd}$ vs. La. F refers to mean degree of melting. CMR: columnar melting regime, TMR: triangular melting regime. Fractional crystallization modelling (10-60\%) of a suitable high Ti-suite primary magma is shown in all diagrams (Momme et al. 2006). Cu, Sm and La values are in $\mu \mathrm{g} / \mathrm{g}$ (ppm). $\mathrm{Pd}$ values in $\mathrm{ng} / \mathrm{g}(\mathrm{ppb})$.

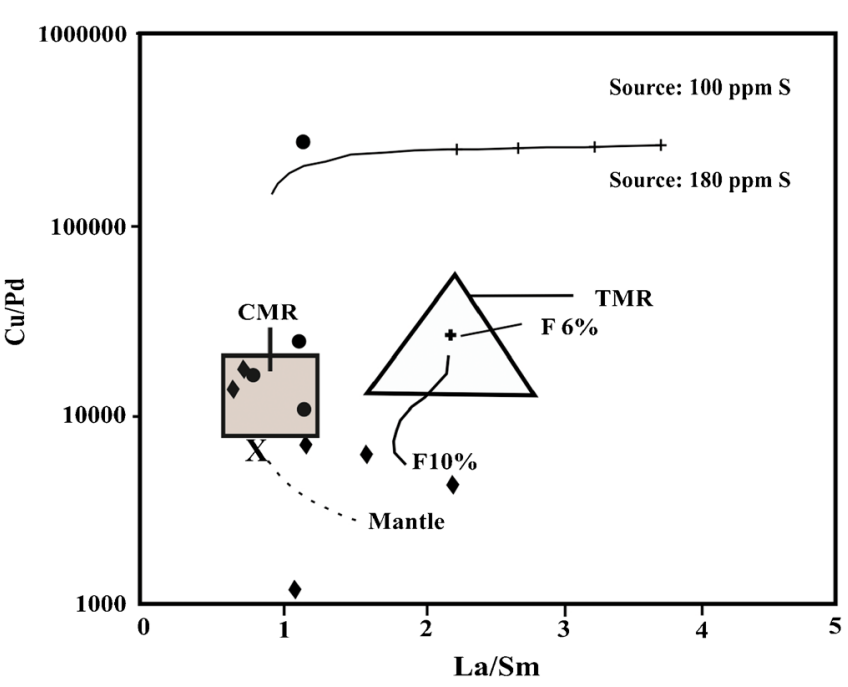

Figure 8. $\mathrm{Cu} / \mathrm{Pd}$ vs. La/ $\mathrm{Sm}$ plot for mafic rocks of east Khasi Hills and mantle melting models. The triangular portion represents most high Ti-suite approximated by triangular melting regime ( $\mathrm{F} \sim 6 \%$ ) ( $\mathrm{F}$ means degree of melting). The square portion represents the low Ti-suite formed from a columnar melting regime ( $\mathrm{F} \sim 19-20 \%)$. This diagram is efficient to discriminate between magmas formed in different melting regimes (Momme et al. 2006).

than $\sim 25 \%$. However, $\mathrm{Cu} / \mathrm{Pd}$ of some sample $(\mathrm{SH}$ 119) (table 3) indicates batch melting of cylindrical column even less than $\sim 25 \%$.

In order to further understand the nature of melting regime (CM or TM) and degree of batch melting of cylindrical column, the investigated mafic rocks (both HT and LT type) have been plotted in $\mathrm{Sm} v s$. La, $\mathrm{Cu}$ vs. La and $\mathrm{Pd}$ vs. La diagrams (figure $7 \mathrm{a}-\mathrm{c}$ ). These diagrams include fields for CMR and TMR as well as fields for mafic rocks of eastern Greenland (Momme et al. 2006). Interestingly, all these diagrams (figure 7) indicate involvement of columnar melting regime with relatively higher degrees of melting $(\sim 20 \%)$. Therefore, combining evidences obtained from concentration of $\mathrm{Cu}, \mathrm{PGE}$ and $\mathrm{REE}$, it may be safely concluded that the parent mafic magma originated by high degree of melting $(\sim 20 \%$ to $\sim 25 \%)$. Figure 8 depicts plots of $\mathrm{Cu} / \mathrm{Pd} v s$. La/Sm and this particularly helps to constrain nature of mantle melting. The triangular field corresponds to triangular melting regime (TMR) which has been generated by $\mathrm{F} \sim 6 \%$ equilibrium batch melting. The square field corresponds to the field of columnar melting regime (CMR) which has been produced by $\mathrm{F} \sim 20 \%$ equilibrium batch melting. The plots for investigated rocks (for both HT and LT types) are clearly discriminated to have been formed by CMR. Mungall and Brenan (2013) have shown that mid oceanic ridge basalts (MORB) are the products of pooled low and high degree fractional melt. A significant control on PGE fractionation in mantle 


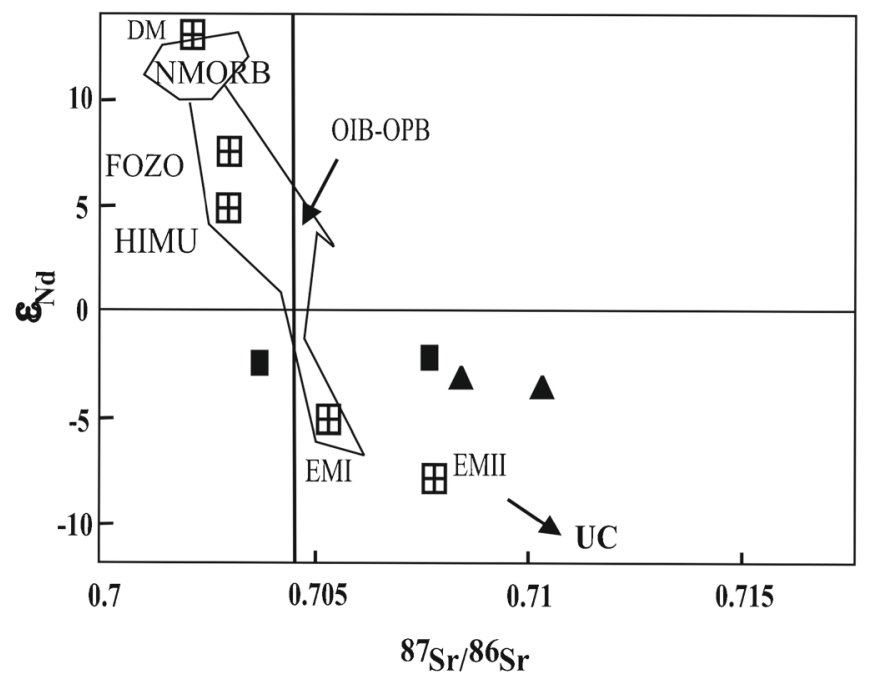

(a)

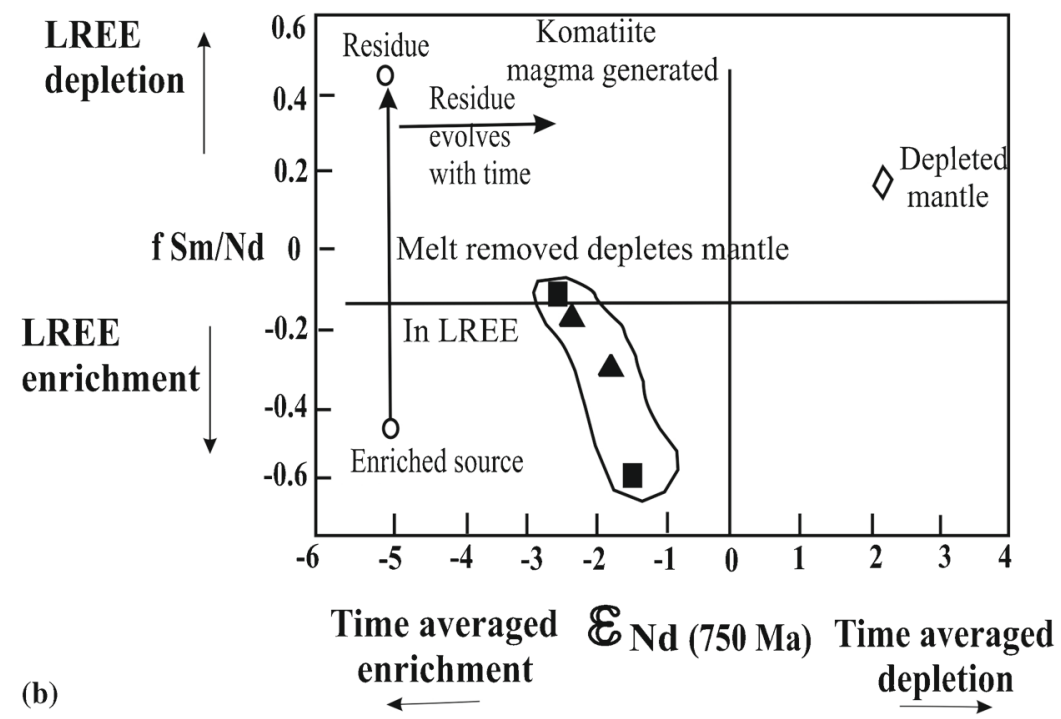

Figure 9. (a) Plots of mafic rocks in $\varepsilon_{\mathrm{Nd}} v s .{ }^{87} \mathrm{Sr} /{ }^{86} \mathrm{Sr}$ ratio diagram basalt from various tectonic settings (after Hofmann 1997) are shown. Here $\mathrm{DM}=$ depleted mantle, $\mathrm{FOZO}=$ focal zone mantle, EMI and EMII=enriched mantle sources, $\mathrm{HIMU}=$ high source, $\mathrm{UC}=$ upper continental crust, $\mathrm{OIB}=$ oceanic island basalts, $\mathrm{OPB}=\mathrm{oceanic}$ plateau basalts, $\mathrm{NMORB}=$ normal oceanic ridge basalts. UC: $\varepsilon_{\mathrm{Nd}}=-22 ;{ }^{87} \mathrm{Sr} /{ }^{86} \mathrm{Sr}=0.725$. The composition of the upper continental crust is marked. (b) $f_{\mathrm{Sm} / \mathrm{Nd}}$ vs. $\varepsilon_{\mathrm{Nd}(750 \mathrm{Ma})}$ diagram, showing the isotopic evolution of the source of the study area (after Shirey and Hanson 1986) (solid square: massive type of mafic rocks, solid triangle: foliated type of mafic rocks).

derived magmas is exerted by residual alloy or PGE minerals in their source. Within-plate picrites are pooled products of larger degrees of fractional melting in columnar melting regimes. In case of MORB-genesis at low pressure, the mantle residual to batch melting of cylindrical column retains the signature of primitive mantle, inter-element ratios and PGE abundances until sulphide has been completely dissolved but then evolves to extremely high $\mathrm{Pt} / \mathrm{Pd}$ and low $\mathrm{Pd} / \mathrm{Ir}$ because $\mathrm{Pt}$ and Ir alloys form in the restite.

Naldrett (2009), on regional review of different PGE deposits of the world, identified several well marked petrotectonic settings which are broadly 'intracratonic', 'intracratonic rift', 'rifted continental margin', 'triple juncture related rift', 'craton boundary with volcano plutonic rocks' and 'orogenic'. Thus, the characteristic PGE behaviours of the presently investigated mafic rocks of east Khasi Hills can be typically classified as 'orogenic (discordant) type'.

Ray et al. (2013), in a previous publication based on $\varepsilon_{\mathrm{Nd}}$ vs. ${ }^{87} \mathrm{Sr} /{ }^{86} \mathrm{Sr}$ suggested that the mafic rocks of the present study have an enriched mantle affinity and they have a co-magmatic lineage (figure 9a and b). Further, the parent melts were originated from an enriched mantle source. The overall $\mathrm{Rb}-\mathrm{Sr}$ and $\mathrm{Sm}-\mathrm{Nd}$ isotopic compositions 


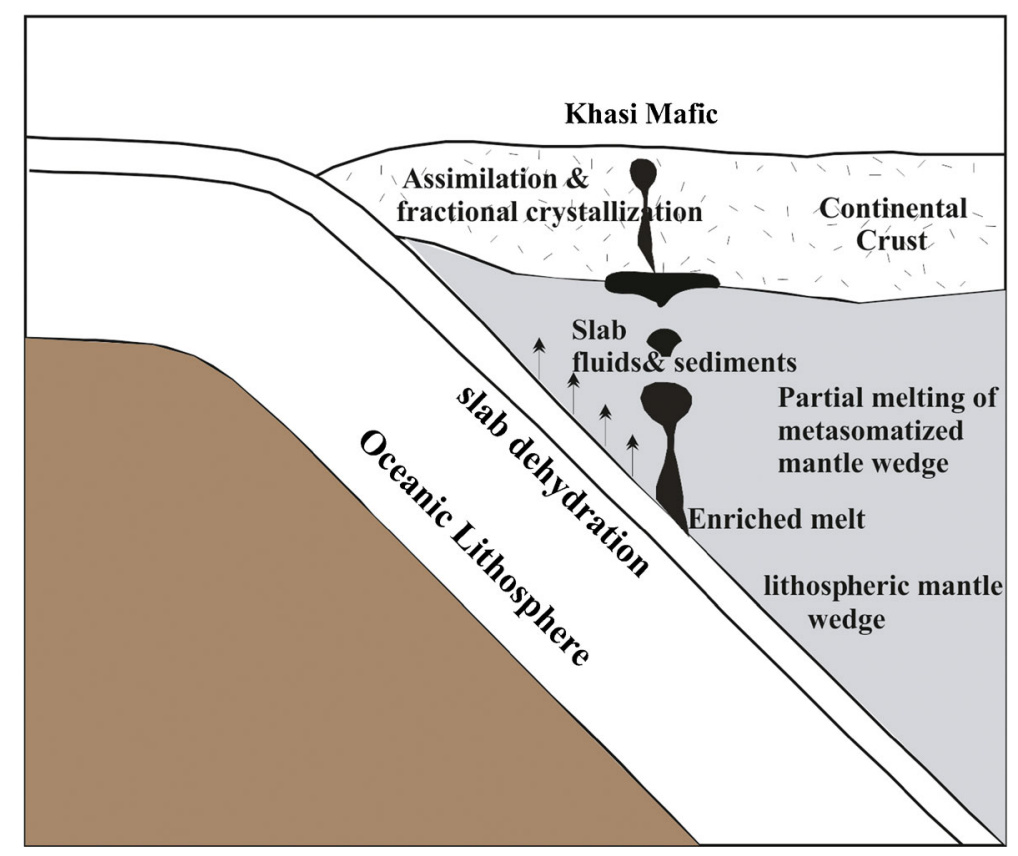

Figure 10. Schematic diagram illustrating the generation of mafic rocks of east Khasi Hills at a continental margin arc setting (data taken from Ray et al. 2013).

marked by strongly positive $\varepsilon_{\mathrm{Sr}}$ and negative $\varepsilon_{\mathrm{Nd}}$ strongly favour an enriched source mantle. The melting behaviour of mantle in orogenic setting is sensitively dependent on $\mathrm{H}_{2} \mathrm{O}$ content and has been determined experimentally up to $40 \mathrm{~kb}$ for $\mathrm{H}_{2} \mathrm{O}$ saturated conditions $\left(6 \% \mathrm{H}_{2} \mathrm{O}\right)$. High degree of melting under $\mathrm{H}_{2} \mathrm{O}$-saturated condition characteristically yield magnesian, quartz-normative basaltic andesite to quartz tholeiite magmas (Green 1973) similar to the mafic rock found during the present investigation. Moreover, the degree of mantle melting is positively and linearly correlated with the proportion of $\mathrm{H}_{2} \mathrm{O}$. In fact, incremental water content in the source mantle depresses its solidus and may produce arc-like basalt (Stolper and Newman 1994; Ulmer 2001). In the present scenario (which entails involvement of columnar melting regime), addition of $\mathrm{H}_{2} \mathrm{O}$ rich components, which might have been derived from fluids from the subducting slab is in conformity with the slab dehydration and wedge melting milieu (Ray et al. 2013). These investigated mafic rocks of east Khasi Hills were generated through slab-dehydration, wedge-melting and assimilation-fractional crystallization process at a continental margin arc setting (figure 10). Continental arc related Proterozoic mafic rocks are now being widely reported from China showing negative $\mathrm{Nb}$ and $\mathrm{Ta}$ anomalies (Zhou et al. 2002, 2004a, b). It is believed that, in the generation of such mafic rocks, magmatism at convergent plate setting is mainly responsible rather than upwelling mantle plume.

\section{Conclusions}

- The mafic rocks of east Khasi Hills of the Meghalaya plateau, northeastern India, occur as an intrusive body, which cut across the Shillong group of rocks.

- The investigated mafic rocks (on the basis of petrography) can be divided into 'massive' and 'foliated type'. On the basis of geochemistry, these can be divided into high-titanium (HT) and low-titanium (LT) types.

- REE and PGE characters clearly indicate role of magmatic differentiation. The PGE behaviours suggest generation of parent magma at a columnar melting regime with batch melting $(\sim 25 \%)$ of cylindrical columns. These mafic rocks can be best described as 'orogenic discordance type' on the basis of PGE-modelling.

- The parent magma has enriched mantle affinity, controlled by slab-dehydration, wedge-melting and assimilation-fractional crystallization at a continental margin arc setting.

\section{Acknowledgements}

Authors thank the Department of Science and Technology (DST), Government of India, for the financial support to carry out this research. The authors are grateful to the Head, Department of Geology, Calcutta University and the Director, CSIRNGRI, for providing necessary laboratory facilities. 


\section{References}

Alapieti T T, Devaraju T C and Kaukonen R J 2008 PGE mineralization in the late Archaean iron-rich maficultramafic Hanumalapur Complex, Karnataka, India; Mineral. Petrol. 92 99-128.

Auge T, Salpeteur I, Bailly L, Mukherjee M M and Patra R N 2002 Magmatic and hydrothermal platinum-group minerals and base-metal sulfides in the Baula complex, India; Canad. Mineral. 40 277-309.

Balaram V 2008 Recent advances in the determination of PGE in exploration studies - A review; J. Geol. Soc. India 72 661-677.

Balaram V and Rao T G 2003 Rapid determination of REE and other trace elements in geological samples by microwave acid digestion and ICP-MS; Atomic Spec. 24 206-212.

Balaram V, Mathur R, Banakar V K, Hein J R, Rao C R M, Rao T G and Dasaram B 2006 Determination of the platinum group elements (PGE) and gold $(\mathrm{Au})$ in manganese nodule reference samples by nickel sulfide fire-assay and Te co-precipitation with ICP-MS; Indian J. Marine Sci. 35 7-16.

Balaram V, Singh S P, Satyanarayanan M and Anjaiah K V 2013 Platinum group elements geochemistry of ultramafic and associated rocks from Pindar in Madawara Igneous Complex, Bundelkhand massif, central India; J. Earth Syst. Sci. 122 79-91.

Barnes S J and Maier W D 1999 The fractionation of Ni, $\mathrm{Cu}$ and the noble metals in silicate and sulfide liquids; In: Dynamic processes in magmatic ore deposits and their application in mineral exploration (eds) Keays $\mathrm{R} R$, Lesher C M, Lightfoot P C and Farrow C E G, Geol. Assoc. Canada 13 69-106.

Barnes S J, Naldrett A J and Gorton M P 1985 The origin of the fractionation of the platinum-group elements in terrestrial magmas; Chem. Geol. 53 303-323.

Barnes S J, Boyd R, Korneliussen A, Nilsson L P, Often M, Pedersen R B and Robins B 1988 The use of mantle normalization and metal ratios in discriminating between effects of partial melting, crystal fractionation and sulphide segregation on platinum-group elements, gold, nickel and copper. Examples from Norway; In: Geo-Platinum '87 (eds) Prichard H M et al. (London: Elsevier), pp. 113-143.

Brügmann G E, Naldrett A J, Asif M, Lightfoot P C, Gorbachev N S and Fedorenko V A 1993 Siderophile and chalcophile metals as tracers of the evolution of the 10 Siberian Trap in the Noril'sk region, Russia; Geochim. Cosmochim. Acta 57 2001-2018.

Cox K G, Bell J D and Pankhurst R J 1979 The Interpretation of Igneous Rocks; George, Allen and Unwin, London.

Crocket J H and Paul D K 2004 Platinum-group elements in Deccan mafic rocks: A comparison of suites differentiated by Ir content; Chem. Geol. 208 273-291.

Devaraju T C, Alapieti T T and Kaukonen R J 2005 SEM-EDS study of the platinum-group minerals in the PGE mineralised Hanumalpura segment of layered mafic ultramafic complex of Channagiri, Devangere district, Karnakataka; J. Geol. Soc. India 65 745-752.

Dora M L, Nair K K K and Shasidharan K 2011 Occurrence of platinum group minerals in the Western Bastar Craton, Chandrapur District, Maharashtra; Curr. Sci. 100 399-404.

Farm M S and Leshar C E 1997 Generation of polybaric differentiation of East Greenland early Tertiary flood basalts; J. Petrol. 38 231-275.
Farooqui S A and Singh A K 2006 Platinum mineralization in Ikauna area, Lalitpur District, Uttar Pradesh; J. Geol. Soc. India 68 582-584.

Green D H 1973 Experimental melting studies on a model upper mantle composition at high pressure under watersaturated and water-undersaturated conditions; Earth Planet. Sci. Lett. 19 37-63.

Hazra S, Ray J and Saha A 2008 Mineral-chemical studies of Proterozoic Mafic suite of rocks of Meghalaya, northeastern India; J. Geol. Soc. India 72 679-690.

Hofmann A W 1997 Mantle geochemistry: The message from oceanic volcanism; Nature 385 219-229.

Hudson D R, Robinson B W, Vigers R B W and Travis G A 1978 Zoned michenerite testibiopalladite from Kambalda, Western Australia; Canad. Mineral. 16 121-126.

Keays R R and Lightfoot P C 2010 Crustal sulfur is required to form magmatic $\mathrm{Ni}-\mathrm{Cu}$ sulfide deposits: Evidence from chalcophile element signatures of Siberian and Deccan Trap basalts; Mineralium Deposita 45 241-257.

Keyas R R 1995 The role of komatiitic magmatism and Ssaturation in the formation of ore deposits; Lithos $\mathbf{3 4}$ $1-18$.

Korenaga J and Kelemen P B 2000 Major element heterogeneity in the mantle source of the North Atlantic igneous province; Earth Planet. Sci. Lett. 184 251-268.

Langmuir C H, Klein E M and Plank T 1992 Petrological systematic of mid-ocean ridge basalts: Constraints on melt generation beneath ocean ridges; In: Mantle flow and melt generation at mid-ocean ridges (eds) Morgan J P, Blackman D K and Sinton J M, Geophys. Monogr. 77 183-275.

Lesher C M and Barnes S J 2009 Komatiite-associated $\mathrm{Ni}-\mathrm{Cu}-(\mathrm{PGE})$ deposits; In: Magmatic Ni-Cu-PGE Deposits. Genetic Models and Exploration (eds) Li C and Ripley E M, Geological Publishing House of China, pp. $27-101$.

Li C, Ripley E M and Naldrett A J 2009 New developments in magmatic Ni-Cu and PGE deposits; Geological Publishing House, Beijing, 290p.

Maier W D 2005 Platinum-group element deposits and occurrences: Mineralisation styles, genetic concepts, and exploration criteria; J. African Earth Sci. 41 165-191.

Maier W D, Barnes S J, Deklerk W J, Teigler B and Mitchell A A $1996 \mathrm{Cu} / \mathrm{Pd}$ and $\mathrm{Cu} / \mathrm{Pt}$ of silicate rocks in the Bushveld complex: Implications for platinum-group element exploration; Econ. Geol. 91 1151-1158.

Mathez E A 1976 Sulfur solubility and magmatic sulphides in submarine basalt glass; J. Geophys. Res. 81(23) 42694276.

Mazumder S K 1986 The Precambrian framework of part of the Khasi Hills, Meghalaya; Geol. Surv. India Record 11(Part 2) 1-59.

McDonough W F and Sun S S 1995 Composition of the Earth; Chem. Geol. 120 223-253.

Momme P, Tenger C, Brooks C K and Keays R R 2002 The behavior of platinum-group elements in basalts from the East Greenland rifted margin; Contrib. Mineral. Petrol. $143133-153$.

Momme P, Oskarsson N and Keays R R 2003 Platinumgroup elements in the Icelandic rift system: Melting processes and mantle sources beneath Iceland; Chem. Geol. $96209-234$.

Momme P, Tenger C and Brooks C K 2006 Two melting regimes during Paleogene flood basalt generation in east Greenland: Combined REE and PGE modeling; Contrib. Mineral. Petrol. 151 88-100.

Mondal S K 2011 Platinum-group element (PGE) geochemistry to understand the chemical evolution of the Earth's mantle; J. Geol. Soc. India 77 295-302. 
Mondal S K, Frei R and Ripley E M 2007 Os isotope systematics of archean Chromite PGE deposits in the Singhbhum craton (India): Implication for the evolution of lithospheric mantle; Chem. Geol. 244 391408.

Mukherjee M M 2010 Exploration for platinum group metals in India - A status note; Proc. Mag. Ore Depo., IMMT, Bhubaneshwar, pp. 1-4.

Mungall J E and Brenan J M 2013 Mantle-crust fractionation of the platinum-group elements; Goldschmidt 2013 Conference Abstracts, doi: 10.1180/minmag.2013.077.5.13.

Nakamura N 1974 Determination of REE, Ba, Fe, Mg, Na and $\mathrm{K}$ in carbonaceous and ordinary chondrites; Geochim. Cosmochim. Acta 38 757-773.

Naldrett A J 2009 Fundamentals of magmatic sulphide deposits; In: New developments in magmatic $\mathrm{Ni}-\mathrm{Cu}$ and PGE deposits (eds) Li C and Ripley M, Geol. Publ. House, Beijing, pp. 1-26.

Naldrett A J 2010 Secular variation of magmatic sulfide deposits and their source magmas; Econ. Geol. Spec. Issue $105669-688$.

Naldrett A J, Hoffman E L, Green A H, Chin-Lin Chou, Naldrett S R and Alcock R A 1979 The composition of Ni-sulfide ores, with particular reference to their content of PGE and Au; Canad. Mineral. 17 403415.

Naldrett A J, Wilson A, Kinnaird J and Chunnett G 2009 PGE tenor and metal ratios within and below the Merensky Reef, Bushveld Complex: Implications for its genesis; J. Petrol. 50 625-659.

Nathan N P 2010 PGE mineralisation in ultramafic-mafic complexes of Tamil Nadu: A preliminary note; J. Geol. Soc. India $\mathbf{7 6} 426$.

Qi L and Zhou M F 2008 Platinum-group elemental and $\mathrm{Sr}-\mathrm{Nd}-\mathrm{Os}$ isotopic geochemistry of Permian Emeishan flood basalts in Guizhou Province, SW China; Chem. Geol. 248 83-103.

Ray J, Saha A, Koeberl C, Thoni M, Ganguly S and Hazra S 2013 Geochemistry and petrogenesis of Proterozoic mafic rocks from east Khasi Hills, Shillong Plateau, northeastern India; Precamb. Res. 230 119137.

Rekhamper M, Halliday A N, Filton J G, Lee D C, Wieneke M and Arndt N T 1999 Ir, Ru, Pt and Pd in basalts and komatiites: New constraints for the geochemical behavior of the platinum group elements in the mantle; Geochim. Cosmochim. Acta 63(22) 3915-3934.

Satio S, Brown M, Korhonen F J, Mc Fadden R R and Siddoaway C S 2013 Petrogenesis of Cretaceous mafic intrusive rocks, Fosdick mountains, west Antarctica: Melting of the sub-continental arc mantle along the Gondwana margin; Gond. Res. 23 1567-1580.

Satyanarayanan M, Subba Rao D V, Charan S N, Anbarasu K, Karthikeyan A, Narsing Rao S, Dasaram B, Sawant S S and Balaram V 2008 Petrological and geochemical characteristics of dunites and the associated granulites of Salem and Nagaramalai areas in Tamil Nadu, southern India; Indian Minerals 42(1) 33-43.

Satyanarayanan M, Balaram V, Parijat R, Anjaiah K V and Singh S P 2010a Trace, REE and PGE geochemistry of the mafic and ultramafic rocks from Bundelkhand craton, central India; Advan. Geosci. 20 57-79.

Satyanarayanan M, Sylvester P J, Balaram V, Rao D V S, Charan S N, Tubrett M N, Shaffer M, Anbarasu K and Karthikeyan A 2010b PGE mineralization in the Late Archaean Sittampundi layered complex, southern India; In: Proc. 11th International Plati. Sympo. Sudbury,
Canada (http://11ips.laurentian.ca/Laurentian/Home/ Departments/Earth+Sciences/NewsEvents/11IPS).

Satyanarayanan M, Balaram V, Singh S P, Sarma D S, Anjaiah K V and Aditya K 2011 Platinum group elements in Madawara Igneous Complex, Bundelkhand massif, central India: Some exciting results; DCS-DST Newsletter, pp. 19-24.

Sheraton J W, Black L P, Mc Culloch M T and Oliver R L 1990 Age and origin of a compositionally varied mafic dyke swarm in the Bunger Hills, East Antarctica; Chem. Geol. 85 215-246.

Shirey S B and Hanson G N 1986 Mantle heterogeneity and crustal recycling in Archean granite-greenstone belts: Evidence from $\mathrm{Nd}$ isotopes and trace elements in the Rainy Lake area, Superior Province, Ontario, Canada; Geochim. Cosmochim. Acta 50 2631-2651.

Singh S P, Balaram V, Satyanarayanan M, Anjaiah K V and Kharya A 2010a Madawara Ultramafics Complex in Bundelkhand Craton: A new PGE repository for exploration in central India; J. Econ. Geol. Georesource Mgt. 7 51-68.

Singh S P, Balaram V, Satyanarayanan M, Anjaiah K V and Kharia A 2010b Platinum group elements in basic and ultrabasic rocks around Madawara, Bundelkhand Massif, central India; Curr. Sci. 99 375-383.

Song X Y, Keays R R, Xiao L, Qi H W and Ihlenfeld C 2009 Platinum-group element geochemistry of the continental flood basalts in the central Emeishan Large Igneous Province, SW China; Chem. Geol. 262 246-261.

Srivastava R K, Mondal S K, Balaram V and Gautam G C 2010 PGE geochemistry of low-Ti high-Mg silicious mafic rocks within the Archaean Central Indian Bastar craton: Implications for magma fractionation; Mineral. Petrol. 98 329-345.

Stolper E and Newman S 1994 The role of water in the petrogenesis of Mariana trough magmas; Earth Planet. Sci. Lett. $121293-325$.

Streckeisen A 1976 To each plutonic rock its proper name; Earth Sci. Rev. 12 1-33.

Suk M 1983 Petrology of metamorphic rocks; Elsevier, $322 \mathrm{p}$.

Sun S S and Mc Donough W F 1989 Chemical and isotopic systematics of oceanic basalts, implications for mantle composition and processes; In: Magmatism in the Ocean Basins (eds) Saunders A D and Norry M J, Geol. Soc. London, Spec. Publ. 42 313-345.

Ulmer P 2001 Partial melting in the mantle wedge the role of $\mathrm{H}_{2} \mathrm{O}$ in the genesis of mantle-derived 'arcrelated' magmas; Phys. Earth Planet. Interiors $\mathbf{1 2 7}$ $215-232$.

Vaillancourt C, Sproule R A, MacDonald C A and Lesher C M 2003 Investigation of mafic-ultramafic intrusions in Ontario and implications for Platinum group element mineralization: Operation treasure hunt; Ontario Geol. Surv., Open File Report 6102, 357p.

West W D 1949 General report of the Geological Survey of India for the year 1939; Rec. Geol. Surv. India 78(1) 57-60.

Woodland S J, Pearson D G and Thirlwall M F 2002 A platinum group element and Re-Os isotope investigation of Siderophile element recycling in subduction zones: Comparison of Grenada, lesser Antilles arc, and the Izu-Bonin arc; J. Petrol. 43 171-198.

Zhao J X, Shiraishi K, Ellis D J and Sheraton J W 1995 Geochemical and isotopic studies of syenites from the Yamato Mountains, East Antarctica: Implications for the origin of syenitic magmas; Geochim. Cosmochim. Acta 59 13631382. 
Zhou M F, Kennedy A K, Sun M, Malpas J and Lesher C M 2002 Neoproterozoic arc related mafic intrusions along the northern margin of South China: Implications for the accretion of Rodinia; J. Geol. 110 611-618.

Zhou J, Wang X, Qiu J and Gao J 2004a Geochemistry of Meso- and Neoproterozoic mafic-ultramafic rocks from northern Guangxi, China: Arc or plume magmatism; Geochem. J. 38 139-152.

Zhou M F, Robinson P T, Malpas J, Edwards S J and Qi L 2004b REE and PGE geochemical constraints on the formation of Dunites in the Luobusa ophiolite, southern Tibet; J. Petrol. 3 1-25.

MS received 12 September 2013; revised 17 September 2014; accepted 18 September 2014 